\title{
ANALISIS KUALITAS GEOMETRIS \\ HASIL PRAKTIK PEMESINAN BUBUT SISWA SMK JURUSAN TEKNIK PEMESINAN
}

\author{
Puji Dwi Utomo ${ }^{1}$, Thomas Sukardi ${ }^{2}$, Sudji Munadi ${ }^{3}$ \\ 1,2,3Pendidikan Teknik Mesin Fakultas Teknik Universitas Negeri Yogyakarta \\ pujidwiutomo@gmail.com
}

\begin{abstract}
This study aims to determine the geometric quality of lathe machining product and what causes the low geometric quality of the lathe machining practices. This research is a descriptive study using a quantitative approach. Data were obtained by documentation and direct observation of the studied object, and then were processed using descriptive statistical analysis. Results show that the average value of the geometric quality of lathe machining products was relatively low, amounted to 67.14. The aspects that caused deficiencies and low geometric quality are, among others, incorrect spindle speed, incorrect feeds, incorrect depth of cuts, improper use of measuring tools, and lack of awareness of the Occupational Safety and Health equipment.
\end{abstract}

Keywords: geometric quality, lathe machining, practice, product

\begin{abstract}
ABSTRAK
Penelitian ini bertujuan untuk mengetahui kualitas geometris produk hasil praktik pemesinan bubut dan penyebab rendahnya kualitas geometris hasil praktik pemesinan bubut. Penelitian ini merupakan jenis penelitian deskriptif dengan menggunakan pendekatan kuantitatif. Data penelitian diperoleh dengan menggunakan dokumentasi dan pengamatan langsung pada obyek yang diteliti kemudian diolah menggunakan analisis statistik deskriptif. Hasil penelitian menunjukkan bahwa rata - rata nilai kualitas geometris hasil praktik pemesinan bubut siswa tergolong rendah yakni sebesar 67,14 serta aspek-aspek yang menjadi penyebab kekurangan dan kelemahan kualitas geometris diantaranya meliputi, kesalahan dalam menentukan putaran mesin, kesalahan dalam menentukan kecepatan gerak pemakanan, tidak tepatnya pengaturan kedalaman pemakanan, kesalahan dalam menggunakan alat ukur serta kurangnya kesadaran akan pentingnya penggunaan perlengkapan K3.
\end{abstract}

Kata kunci: kualitas geometris, praktik pemesinan bubut, produk pemesinan bubut

\section{PENDAHULUAN}

Prestasi belajar merupakan tolok ukur pengetahuan dan keterampilan siswa pada suatu bidang tertentu. Namun, pada pelaksanaannya sering dijumpai institusi pendidikan tidak melakukan penilaian sesuai dengan standar penilaian hasil praktik keterampilan yang benar karena lebih menitikberatkan pada ketercapaian batas nilai tertentu atau standar KKM. Penilaian yang dalam garis besar seharusnya meliputi keseluruhan aspek kualitas geometris yang diantaranya dimensi yang tepat, bentuk yang ideal dan tingkat kekasaran/performa yang baik (Rochim: 2001). Penilaian yang dilakukan gutu hanya mengambil beberapa keriteria saja, sehingga yang seharusnya benda kerja belum memenuhi standar dapat lulus penilaian. Hal ini akan mengakibatkan seorang siswa mengalami penurunan kualitas dari segi keahlian dan keterampilan. Rendahnya kualitas produk hasil praktik merupakan salah satu bukti bahwa siswa belum menguasai kompetensi yang diajarkan, padahal dalam dunia kerja selalu dituntut untuk memiliki kompetensi yang baik dan berkualitas. Hal ini sejalan dengan adanya temuan mengenai terjadinya penurunan kualitas produk pada LKS SMK se-DIY (Panji Winarno: 2014).

Pendidikan tidak hanya berfungsi sebagai pemasok tenaga kerja, namun dituntut menghasilkan lulusan yang memang benarbenar dibutuhkan oleh masyarakat dan dunia kerja (Arif Marwanto: 2008). Pendidikan 
sebagai media untuk meningkatkan kualitas kompetensi siswa sesuai tuntutan dunia kerja dapat mengupayakan berbagai tindakan yang akan meningkatkan kualitas kompetensi siswa. Peningkatan kualitas kompetensi siswa dapat dilakukan dengan cara memperbaiki sistem pembelajaran. Pembelajaran dengan model atau strategi yang tepat dapat meningkatkan mutu pendidikan (Sutopo: 2008). Dengan sistem pembelajaran yang benar maka kualitas produk hasil praktik yang dihasilkan pun juga akan tinggi.. Hal ini sesuai dengan sistem yang diterapkan di industri dimana produk yang dihasilkan harus sesuai dengan permintaan dengan mempertimbangkan kepresisian, kesesuaian bentuk dan tampilan yang baik.

SMK sebagai lembaga pendidikan yang menyiapkan siswanya untuk terjun dalam dunia kerja setelah lulus, kurikulum SMK Muhammadiyah 1 Bantul mencantumkan penguasaan pengoperasian mesin bubut sebagai salah satu kualifikasi keterampilan dasar. Salah satu kompetensi pada kelas teknik pemesinan kelas XI yaitu pelajaran proses pemesinan bubut, merupakan salah satu mata pelajaran produktif yang wajib lulus oleh kelas XI di jurusan teknik pemesinan SMK Muhammadiyah 1 Bantul. Pelajaran proses pemesinan bubut ini mempunyai perangkat pembelajaran seperti pelajaran yang lain diantaranya kurikulum berbasis kompetensi, silabus dan rencana pelaksanaan pembelajaran. Berdasarkan pengamatan awal yang dilakukan diperoleh banyaknya benda kerja hasil praktik bubut yang sebenarnya tidak sesuai dengan kriteria penilaian yang secara garis besar meliputi dimensi yang tepat, bentuk yang ideal dan tingkat kekasaran/performa yang baik lulus dalam penilaian. Oleh karena itu perlu adanya analisis terhadap kualitas geometri hasil praktik bubut sehingga guru dapat mengetahui seberapa besar kualitas geometris produk hasil praktik bubut siswa yang sebenarnya. Dengan demikian guru dapat menentukan layak tidaknya produk hasil praktik bubut tersebut untuk digunakan atau dijual.
Proses pemesinan bubut merupakan salah satu kompetensi yang dibutuhkan oleh dunia industri. Oleh karena itu dalam penyelenggaraan pembelajaran harus sesuai dengan standar yang benar sehingga menghasilkan produk yang berkualitas tinggi. Dari hasil analilis kualitas produk, siswa dapat mengevaluasi sejauh mana ketrampilan yang mereka kuasai sehingga dapat memotivasi siswa untuk lebih meningkatkan kompetensi mereka. Usaha untuk membentuk kompetensi harus dengan praktik yang dilakukan berulangulang sehingga akan terbentuk tindakan yang otomatis (Paryanto: 2008).

Berdasarkan uraian di atas maka kualitas produk yang dihasilkan dari proses pembelajaran praktik sangatlah penting. Dengan mengetahui kualitas produk yang dihasilkan maka juga dapat diketahui pula sejauh mana kompetensi yang dikuasai siswa. Penelitian tentang analisis kualitas geometris hasil praktik pemesinan bubut harus segera dilakukan untuk mengetahui seberapa besar kualitas produk yang dihasilkan dan sebagai informasi yang berguna untuk penyelenggaraan pembelajaran yang baik pada pelajaran proses pemesinan bubut. Pembelajaran yang berkualitas akan berpengaruh pada kualitas mutu pendidikan yang dihasilkan. Dengan demikian lulusan SMK akan mempunyai bekal kompetensi yang cukup dalam bersaing di dunia industri atau dunia kerja.

Penelitian ini bertujuan untuk mengetahui kualitas geometris hasil praktik pemesinan bubut yang sebenarnya dan untuk mengetahui penyebab rendahnya kualitas geometris hasil praktik pemesinan bubut di SMK. Hasil dari penelitian ini dapat dijadikan sebagai informasi dan bahan evaluai guru untuk meningkatkan kualitas pembelajaran sehingga menghasilkan lulusan yang berkompeten dan memiliki keterampilan sesuai dengan bidangnya. 


\section{METODE}

Penelitian yang dilakukan merupakan penelitian deskriptif dengan pendekatan kuantitatif. Penelitian deskriptif yaitu penelitian yang dilakukan untuk mengetahui nilai variabel mandiri, baik satu variabel atau lebih (independen) tanpa membuat perbandingan, atau menghubungkan dengan variabel yang lain (Sugiyono, 2012:13). Penelitian deskriptif dalam penelitian ini dimaksudkan untuk mendapatkan gambaran dan keterangan mengenai hasil analisis kualitas geometris pada hasil praktik proses pemesinan bubut siswa SMK kelas XI Jurusan Teknik Pemesinan.

Penelitian ini dilaksanakan di SMK Muhammadiyah 1 Bantul (Jl. Parangtritis Km.12 Manding, Trirenggo, Bantul). Populasi dalam penelitian ini yaitu siswa kelas XI TP1, XI TP2, dan XI TP3 Jurusan Teknik Pemesinan SMK Muhammadiyah 1 Bantul yaitu berjumlah 101 siswa. Sampel penelitian ini diambil dengan menggunakan teknik proportionate simple random sampling atau diambil secara acak dengan proporsi yang sama di setiap kelasnya mengingat penelitian ini bersifat homogen. Ukuran sampel dari populasi ini ditentukan dengan rumus yang dikembangkan dari Isaac dan Michael. Dengan taraf kesalahan 5\% sehingga diperoleh jumlah sampel sebanyak 81 siswa.

Prosedur penelitian dilaksanakan sebagaimana dijelaskan oleh Sukardi ( 2003) yaitu: (1) mengidentifikasi permasalahan yang signifikan untuk dipecahkan, (2) membatasi dan merumuskan masalah dengan jelas, menentukan tujuan dan manfaat penelitian, (4) melakukan studi pustaka, (5) menentukan kerangka berpikir, dan pertanyaan penelitian dan atau hipotesis penelitian, (6) membuat desain penelitian yaitu menentukan: populasi, sampel, teknik sampling, instrumen, pengumpulan data dan analisis data, (7) mengumpulkan, mengorganisasi, dan menganalisis data dengan menggunakan teknik statistika yang relevan, (8) membuat laporan penelitian.
Data yang diperoleh merupakan hasil pengamatan proses kerja, hasil penilaian kualitas geometris benda kerja dan hasil penilaian oleh guru. Instrumen yang digunakan yaitu lembar pengamatan proses kerja bubut dan lembar penilaian kualitas geometris benda kerja. Teknik pengumpulan data dilakukan dengan pengamatan dan dokumentasi. Analisis data pada penelitian ini menggunakan analisis statistik deskriptif. Adapun analisis statistik yang digunakan yaitu menghitung rata-rata (mean), modus, median, nilai tertinggi, nilai terendah dan persentase.

\section{HASIL DAN PEMBAHASAN}

Hasil penelitian yang diperoleh dalam penelitian ini berupa data lengkap mengenai hasil praktik pemesinan siswa kelas XI Jurusan Teknik Pemesinan SMK Muhammadiyah 1 Bantul yaitu meliputi lembar penilaian kualitas geometris hasil praktik pemesinan bubut, lembar pengamatan proses pemesinan bubut, dan dokumentasi berupa foto selama proses pemesinan berlangsung dan dokumen hasil penilaian hasil praktik siswa oleh guru.

Secara umum hasil penilaian kualitas geometris produk hasil praktik proses pemesinan bubut dapat dilihat pada Tabel 1.

Tabel 1. Hasil Analisis Deskriptif Kualitas Geometris Benda Kerja

\begin{tabular}{llc}
\hline No. & \multicolumn{1}{c}{ Jenis Data } & Skor \\
\hline 1. & Rata - rata (mean) & 67,14 \\
2. & Modus & 72,37 \\
3. & Median & 68,53 \\
4. & Nilai Tertinggi & 83,51 \\
5. & Nilai Terendah & 41,51 \\
\hline
\end{tabular}

Tabel 1 menunjukkan bahwa rata-rata nilai kualitas geometris benda kerja hasil praktik pemesinan bubut tergolong rendah bahkan jauh di bawah kriteria ketuntasan minimal (KKM) 77. Hal tersebut dapat terjadi karena lebih dari 50\% obyek yang diteliti mendapatkan nilai dibawah 70 . Menurut data tersebut hanya ada 8 siswa yang niliainya memenuhi kriteria ketuntasan minimal atau lulus. Hal tersebut membuktikan bahwa hanya 
9,88\% saja siswa yang lulus dari jumlah total 81 responden yang diteiti.

Rendahnya nilai kualitas geometris benda kerja hasil pemesinan bubut membuktikan bahwa siswa belum memiliki kompetensi yang cukup dalam membubut. Hal tersebut disebabkan oleh beberapa hal diantaranya kompetensi siswa dalam mengulir masih rendah, banyak siswa yang tidak mampu menentukan putaran mesin, siswa tidak menggunakan skala nonius eretan mesin bubut dalam menentukan kedalaman pemakanan, sebagian besar siswa tidak melakukan pembubutan finishing, sebagian besar siswa salah dalam pemahaman ukuran dalam chamfer, terbatasnya waktu sehingga ada beberapa siswa yang belum menyelesaiakan job dan kesadaran siswa akan penggunaaan alat keselamatan kerja yang sangat rendah.

Tabel 1 juga menunjukkan bahwa nilai kualitas geometris tertinggi yaitu sebesar 83,51. Siswa yang mampu mendapatkan nilai kualitas geometris tersebut telah menyelesaikan job dengan baik yaitu sebagian besar ukuran yang telah diukur tepat dan berada dalam toleransi yang diijinkan. Sebaliknya nilai terendah yaitu sebesar 41,51 menunjukkan rendahnya kompetensi siswa tersebut dalam membubut. Hal tersebut dapat terjadi karena siswa tidak menyelesaikan beberapa bagian dalam job yang diantaranya penguliran, tirus dan pengeboran. sehingga karena beberapa job tersebut menyumbangkan skor yang tinggi maka nilai akhir menjadi rendah.

Penilaian kualitas geometris dapat dijabarkan berdasarkan beberapa aspek yaitu: ketepatan ukuran, bentuk, dan performa. Penilaian ketepatan ukuran digunakan untuk mengetahui tingkat kesesuaian ukuran produk dengan ukuran pada gambar kerja, untuk mengetahui tingkat kesesuaian ukuran maka dilakukan pengukuran terhadap beberapa aspek ukur. Hasil penilaian berdasarkan aspek ketepatan ukuran sebagaimana ditunjukkan pada Gambar 1.

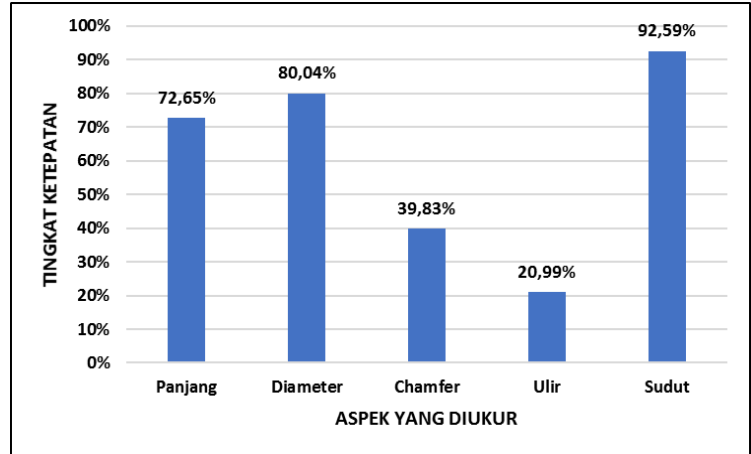

Gambar 1. Tingkat ketepatan ukuran berdasarkan pengukuran yang dilakukan pada benda kerja.

Gambar 1 menunjukkan bahwa siswa paling menguasai dalam membubut suatu sudut atau tirus yaitu sebesar 92,59\%. Hal ini dikarenakan dalam pembubutan tirus siswa hanya perlu mengatur posisi eretan atas membentuk sudut $83^{\circ}$ untuk melakukan pembubutan tirus sehingga dengan mudah tirus dengan sudut $83^{\circ}$ dapat terbentuk. Dalam pembubutan tirus kesalahan yang terjadi diantaranya tidak stabilnya gerak pemakanan sehingga menyebabkan permukaan benda pada tirus tidak rata atau bergelombang. Hal ini dapat diminimalisir dengan menggunakan otomatisasi mesin sesuai dengan kecepatan gerak pemakanan yang dibutuhkan untuk pembubutan tirus.

Gambar 1 juga menunjukkan bahwa siswa lebih menguasai dalam pembubutan diameter dari pada pembubutan panjang dengan tingkat ketepatan ukuran pada pembubutan diameter sebesar $80,04 \%$ dan pembubutan panjang sebesar $72,65 \%$. Hal ini dapat terjadi karena dalam melakukan pemakanan benda kerja siswa lebih mudah untuk mengukur diameter dari pada panjang benda kerja. Setiap siswa melakukan pengukuran kedalaman pemakanan dengan menggunakan jangka sorong sehingga setiap kali setelah pemakanan benda kerja langsung diukur menggunakan jangka sorong untuk memastikan ketepatan ukurannya. Pada saat benda kerja masih terpasang pengukuran diameter jauh lebih mudah karena menggunakan rahang utama. Berbeda ketika pengukuran panjang yaitu saat posisi benda masih terpasang akan sulit karena 
menggunakan indikator pengukur kedalaman. Sebagian besar siswa tidak dapat menggunakan skala nonius pada handle eretan untuk menentukan kedalaman pemakanan sehingga pengukuran dilakukan dengan menggunakan jangka sorong yang menyebabkan sering terjadi ukuran tidak sesuai dan tidak masuk dalam toleransi yang diizinkan.

Pembubutan ulir sebagian besar siswa belum mampu membubut ulir dengan ketepatan ukuran yang benar karena dari sebagian besar ulir yang sudah jadi masih belum tepat ukurannya dan ada beberapa siswa yang belum menyelesaikan pembubutan ulir. Tingkat kesesuaian ukuran hanya $20,99 \%$ saja, nilai tersebut sangat rendah mengingat ulir yang dikerjakan masih sederhana dan harus dijadikan sebagai bahan evaluasi bagi guru untuk lebih meningkatkan pembelajaran praktik mengulir. Rendahnya persentase ketepatan ukuran dalam penguliran disebabkan oleh beberapa hal diantaranya sebagian besar siswa baru pertama kali melakukan praktik penguliran sehingga belum terbiasa menguir, sudut alat potong atau pahat ulir yang yang digunakan kurang tepat dan ukuran awal diameter yang akan diulir kurang tepat. Kemudian rendahnya persentase ketepatan ukuran pada penguliran juga disebabkan karena beberapa siswa belum menyelesaikan penguliran.

Pembubutan chamfer banyak siswa yang mengabaikan ukuran yang ada pada gambar kerja. Hal tersebut terbukti pada hasil chamfer benda kerja, ukuran yang dihasilkan banyak yang tidak sesuai dengan ukuran yang diminta sehingga dalam pembubutan chamfer tingkat ketepatan ukuran hanya sebesar 39,83\%. Hal lain yang menyebabkan rendahnya persentase ketepatan ukuran pada chamfer yaitu karena pemahaman siswa terhadap panjang chamfer yang salah. Yaitu siswa menganggap untuk ukuran chamfer $2 \mathrm{~mm}$ maka yang diukur adalah panjang dari sisi miring yang terbentuk dari pemakanan chamfer tersebut sehingga ukuran chamfer yang diminta tidak tercapai.

Penilaian bentuk digunakan untuk mengetahui tingkat keidealan bentuk benda kerja hasil praktik pemesinan bubut yang dilakukan oleh siswa. Tingkat keidealan bentuk dapat diketahui dengan melakukan penilaian terhadap beberapa aspek ukur, yaitu kelurusan, kesikuan, kesejajaran dan kerataan. Hasil penilaian sebagaimana ditunjukkan pada Gambar 2.



Gambar 2. Diagram Tingkat Kesesuaian Bentuk

Gambar 2 menunjukkan bahwa sebagian besar bentuk benda kerja hasil praktik pemesinan sudah sesuai dan baik yakni dengan masing masing aspek mempunyai tingkat kesesuaian yang tinggi diantaranya kelurusan 99,26\%, kesikuan 98,52\%, dan kesejajaran $99,26 \%$, akan tetapi untuk kerataan benda kerja tingkat kesesuaiannya hanya $82,96 \%$. Hal ini dapat terjadi karena ada beberapa benda kerja yang mempunyai permukaan bergelombang akibat tidak stabilnya gerakan pemakanan pada saat pembubutan, pahat yang sudah tumpul, dan putaran benda kerja yang tidak stabil atau goyang. Tidak stabilnya gerakan pemakanan disebabkan karena gerak pemakanan dilakukan secara manual. Dalam praktiknya siswa tidak dapat menggunakan otomatisasi mesin karena untuk beberapa mesin sudah tidak berfungsi dan belum diajarkan oleh guru yang bersangkutan.

Penilaian performa digunakan untuk mengetahui performa benda kerja hasil praktik pemesinan bubut. Performa benda kerja dapat diketahui dengan melakukan penilaian pada beberapa aspek ukur sebagaimana ditunjukkan pada Gambar 3. 


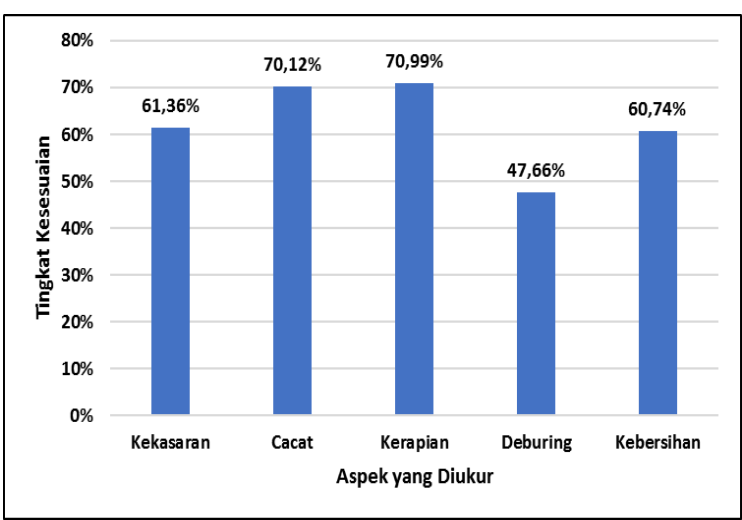

Gambar 3. Tingkat Performa Benda Kerja

Gambar 3 menunjukkan bahwa tingkat performa kekasaran benda kerja 61,36\% maka nilai tersebut tergolong rendah sehingga dapat dikatakan bahwa permukaan benda kerja masih kasar dan belum sesuai dengan standar kekasaran hasil proses bubut. Hal tersebut dapat terjadi karena masih banyak siswa yang tidak bisa menentukan putaran mesin untuk pembubutan diameter tertentu dan juga banyak siswa yang tidak melakukan proses finishing sehingga benda kerja masih kasar. Kurangnya peran guru dalam menekankan pentingnya proses finishing menjadi penyebab utama siswa tidak melakukan pembubutan finishing.

Tidak adanya cacat pada benda kerja menunjukkan tingkat performanya sebesar $70,12 \%$. Dengan persentase tersebut maka masih terdapat kecacatan pada benda kerja. Cacat pada benda kerja dapat terjadi karena pada saat proses pencekaman, benda kerja yang tidak terlindungi tertekan oleh cekam dan meninggalkan bekas. Selanjutnya cacat terdapat pada ulir karena kegagalan penguliran.

Performa kerapian benda kerja mempunyai persentase sebesar 70,99\%. Dengan nilai tersebut beberapa benda kerja siswa tidak rapi dan hal tersebut sebagian besar terdapat pada bagian ulir. Kedalaman pemakanan dan tumpulnya pahat ulir menjadi penyebab tidak rapinya ulir yang dihasilkan. Setelah itu dengan tingkat performa $47,66 \%$ deburing menjadi yang ter rendah. Hal tersebut terbukti karena sebagian besar siswa tidak melakukan deburing sehingga pada bagian ujung atau tepi permukaan benda kerja masih tajam.
Kebersihan benda kerja memiliki tingkat performa sebesar $60,47 \%$. Dengan nilai tersebut maka tingkat kebersihan benda kerja masih rendah. Hal tersebut disebabkan karena banyaknya sisa bram yang masih menempel pada benda kerja dan belum dibersihkan. Tidak adanya pelumasan pada benda kerja sehingga terjadi korosi yang menyebabkan kotornya benda kerja.

Hasil penilaian kualitas geometris sudah dipaparkan di atas, selanjutnya disajikan data hasil pengamatan proses kerja praktik pemesinan bubut siswa kelas XI Jurusan Teknik Pemesinan SMK Muhammadiyah 1 Bantul. Dalam melakukan pengamatan proses kerja bubut maka digunakan indikator yang ingin dicapai diantaranya adalah ketepatan langkah kerja, ketepatan penggunaan mesin dan alat bantu, ketepatan penggunaan alat ukur, melakukan perawatan mesin dan alat ukur, dan keselamatan kerja.

Sebagian besar siswa tidak bisa menentukan putaran mesin untuk suatu pekerjaan pembubutan tertentu. Sehingga dalam praktiknya untuk beberapa pembubutan dengan jenis yang berbeda putaran mesin yang digunakan tetaplah sama. Hal tersebut dibuktikan dengan data persentase siswa yang mampu menentukan dan mengatur putaran mesin hanya $47,44 \%$ sebagaimana ditunjukkan pada Gambar 4. Putaran mesin yang tidak sesuai dalam suatu pekerjaan bubut akan memengaruhi hasil kekasaran benda kerja dan menyebabkan rendahnya tingkat performa benda kerja. Sehingga hasil kekasaran benda kerja hanya mempunyai tingkat performa sebesar $61,36 \%$ saja sebagaimana ditunjukkan pada Gambar 3. Tidak sesuainya putaran mesin juga akan berpengaruh pada hal - hal berikut diantaranya waktu penyelesaian job yang semakin lama, timbulnya kebisingan karena penyayatan benda kerja menimbulkan bunyi yang mengganggu dan proses penumpulan pahat yang semakin cepat. 


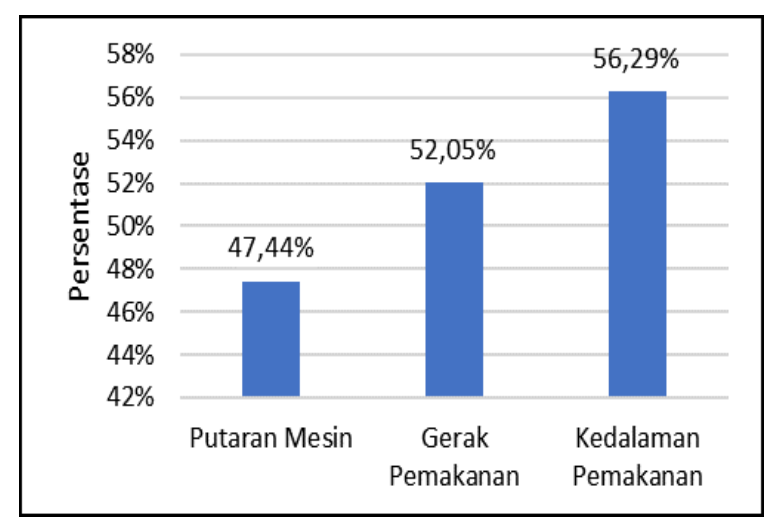

Gambar 4. Persentase Ketepatan Langkah Kerja

Gerak pemakanan yang tidak stabil dapat menyebabkan tidak ratanya suatu permukaan benda kerja. Sebagian besar siswa tidak menggunakan otomatisasi mesin saat melakukan pemakanan benda kerja. Data menunjukkan hanya sebesar 52\% siswa yang dapat mengatur gerakan pemakanan sebagaimana ditunjukkan pada Gambar 4. Dalam prosesnya eretan digerakkan manual karena beberapa mesin sudah mengalami gagal fungsi untuk otomatisasi gerak pemakanan sehingga kestabilan gerakan pemakanan rendah. Hal tersebut dapat mempengaruhi hasil pembubutan dan terbukti bahwa tingkat kerataan benda kerja sebesar 82,96\% sebagaimana ditunjukkan pada Gambar 2. Dengan nilai tersebut dapat dijelaskan bahwa beberapa benda kerja siswa tidak rata karena adanya cekungan pada permukaan benda kerja yang disebabkan oleh ketidakstabilan gerakan pemakanan pembubutan. Ketidakrataan benda kerja dapat mempengaruhi kualitas geometris sehingga menyebabkan rendahnya kualitas geometris benda.

Data pada Gambar 4 menunjukkan hanya $56,29 \%$ siswa yang mampu mengatur kedalaman pemakanan benda kerja. Sebagian besar siswa tidak bisa mengatur kedalaman pemakanan menggunakan skala nonius yang terletak pada handel eretan mesin. Penentuan kedalaman pemakanan dilakukan dengan menggunakan jangka sorong dengan mengukur kedalamannya kemudian diberi tanda. Hal tersebut akan mempengaruhi ketepatan ukuran benda kerja karena dengan memberikan tanda pada benda kerja dengan menggunakan jangka sorong menyalahi prosedur proses kerja bubut. Jangka sorong seharusnya digunakan untuk memastikan ketepatan ukuran setelah proses pemakanan bukan untuk mengukur kedalaman pemakan atau panjang pembubutan yang akan dilakukan.

Beberapa siswa tidak bisa mengatur handel yang terdapat pada mesin bubut. Handel tersebut diantaranya berfungsi untuk mengubah kecepatan putaran mesin, mengatur kecepatan gerak pemakanan, dan pengaturan pembubutan ulir. Data pada Gambar 5 menunjukkan $86,42 \%$ siswa yang dapat mengatur handel tersebut sehingga masih ada beberapa siswa yang tidak pernah menggunakan dan mengatur handel dalam proses kerja bubut. Tentu saja hal tersebut akan mempengaruhi kualitas hasil pembubutan. Penggunaan mesin bubut secara bergantian menjadi salah satu faktor yang menyebabkan siswa tidak mampu mengatur handel mesin sendiri. Sebagai contoh untuk melakukan proses penguliran membutuhkan pengaturan handel proses penguliran. Akan tetapi pada saat praktik penguliran siswa tidak perlu mengatur ulang handel mesin karena sudah ter-setting pada proses penguliran oleh praktikan sebelumnya.



Gambar 5. Persentase Ketepatan Penggunaan Mesin dan Alat Bantu

Data pada Gambar 6 menunjukkan $51,85 \%$ siswa mengikuti prosedur penggunaan alat ukur dengan benar. Penggunaan alat ukur sangat penting dalam proses kerja bubut karena akan mempengaruhi tingkat kepresisian benda kerja. Hal ini menunjukkan bahwa masih 
banyak siswa yang tidak mengikuti prosedur penggunaan alat ukur dengan baik dan benar. Oleh karena itu hal tersebut dapat mempengaruhi kualitas kepresisian benda kerja hasil praktik pemesinan bubut. Kesalahan prosedur pengunaan alat ukur diantaranya yaitu seringnya lepas pasang benda kerja hanya untuk mengukur benda kerja. Karena untuk memasang ulang benda kerja membutuhkan waktu maka pekerjaan menjadi tidak efisien. Kemudian setelah pemakaian, alat ukur tidak diberi pelumas sehingga akan mempercepat terjadinya kerusakaan pada alat ukur yang berpengaruh pada ketelitian alat ukur.

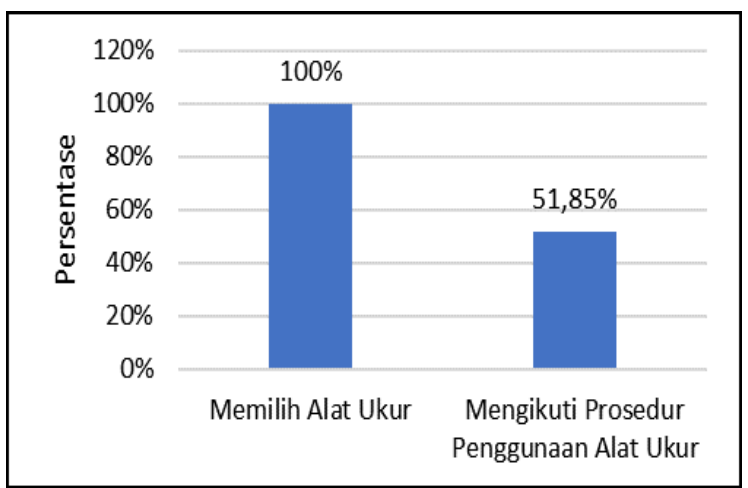

Gambar 6. Persentase Ketepatan Penggunaan Alat Ukur

Sebagian besar siswa tidak melakukan pelumasan pada mesin dan alat bantu. Hal tersebut didukung oleh data yang menunjukkan bahwa $2,46 \%$ saja siswa yang melakukan pelumasan sebagaimana ditunjukkan pada Gambar 7. Sedikitnya siswa yang melakukan pelumasan pada mesin dan alat bantu dikarenakan tidak adanya perintah dari guru untuk memberikan pelumasan setelah selesai praktik. Kemudian tidak tersedianya pelumas yang digunakan untuk melumasi mesin dan alat bantu. Mesin yang digunakan terus menerus membutuhkan pelumasan yang baik. Mesin yang tidak diberi pelumas secara berkala maka kinerja mesin sedikit demi sedikit akan mengalami penurunan sehingga mempengaruhi hasil pembubutan.



Gambar 7. Persentase Perawatan Mesin dan Alat Ukur

Data pada Gambar 8 menunjukkan bahwa hanya $4 \%$ saja siswa yang menggunakan perlengkapan K3. Perlengkapan K3 sangat penting dan harus digunakan ketika melakukan pekerjaan bubut. Kurangnya kesadaran akan bahaya terjadinya kecelakaan merupakan faktor utama yang menyebabkan siswa tidak menggunakan perlengkapan K3. Dengan menggunakan perlengkapan K3 maka dalam melakukan pekerjaan akan lebih nyaman dan berkurangnya rasa khawatir akan terjadinya kecelakaan karena anggota tubuh sudah terlindungi oleh perlengkapan K3. Berbeda halnya jika tidak menggunakan perlengkapan K3 maka dalam melakukan pekerjaan tidaklah nyaman karena rasa khawatir akan terjadinya kecelakaan. Maka dapat disimpulkan bahwa penggunaan perlengkapan K3 akan mempengaruhi kenyamanan proses kerja sehingga akan berpengaruh juga pada hasil kerja pembubutan.

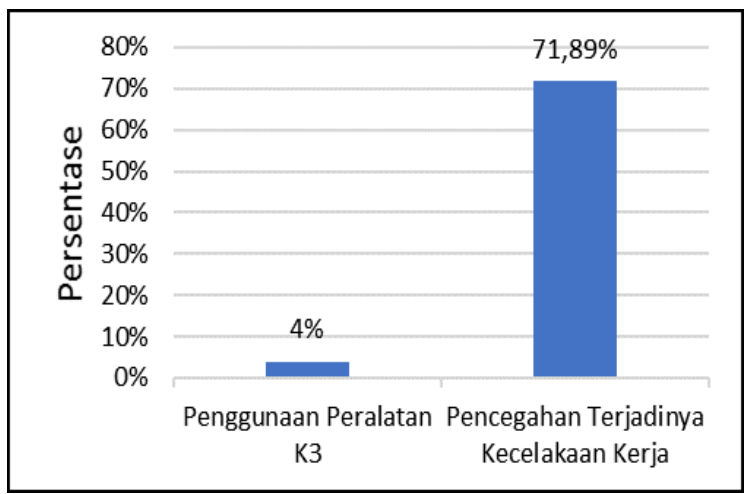

Gambar 8. Penerapan K3 


\section{SIMPULAN}

Rata - rata nilai kualitas geometris hasil praktik pemesinan bubut siswa tergolong rendah yakni sebesar 67,14. Aspek-aspek yang menjadi penyebab kekurangan dan kelemahan kualitas geometris diantaranya meliputi, kesalahan dalam menentukan putaran mesin, kesalahan dalam menentukan kecepatan gerak pemakanan, tidak tepatnya pengaturan kedalaman pemakanan, kesalahan dalam menggunakan alat ukur serta kurangnya kesadaran akan pentingnya penggunaan perlengkapan K3.

Melihat rata-rata nilai kualitas geometris hasil praktik pemesinan bubut siswa kelas XI Jurusan Teknik Pemesinan SMK Muhammadiyah 1 Bantul yang tergolong rendah maka perlu dilakukan perbaikan dalam melakukan pendampingan pada proses pembelajaran berlangsung. Penilaian dilakukan dengan menggunakan panduan penyekoran yang jelas dan obyektif sehingga kompetensi siswa yang sesungguhnya dapat diketahui, kemudian digunakan sebagai bahan evaluasi untuk memperbaiki kualitas pembelajaran. Upaya peningkatan kompetensi siswa dapat dilakukan dengan meningkatkan kualitas pembelajaran dengan mempertimbangkan aspek-aspek yang menjadi kelemahan dan kekurangan dari hasil analisis kualitas geometris hasil praktik pemesinan bubut siswa

\section{DAFTAR RUJUKAN}

Arif Marwanto. (2008). Kesesuaian Pola Mengajar Guru SMK di DIY dengan Tuntutan Pembelajaran dalam Penerapan Kurikulum Tingkat Satuan Pendidikan (KTSP). Jurnal Pendidikan Teknologi dan Kejuruan, 17 (1), 24-38.

Panji Winarno. (2014). Analisis Hasil Lomba Kompetensi Siswa Sekolah Menengah Kejuruan Bidang Las Provinsi Daerah Istimewa Yogyakarta. Skripsi, tidak dipublikasikan. Universitas Negeri Yogyakarta.

Paryanto. (2008). Evaluasi Pelaksanaan Praktik Pemesinan Mahasiswa D3 Teknik Mesin UNY. Jurnal Pendidikan Teknologi dan Kejuruan, 17 (1), 100-118.

Sugiyono (2012). Statistika untuk Penelitian. Bandung: CV Alvabeta.

Sukardi (2003). Metodologi Penelitian Pendidikan: Kompetensi dan Prakteknya. Jakarta: PT Bumi Aksara.

Sutopo. (2008). Penerapan Model Pembelajaran ALGORITMA-HEURISTIK Sebagai Upaya untuk Meningkatkan Kualitas Pembelajaran Praktik Pemesinan. Jurnal Pendidikan Teknologi dan Kejuruan, 17 (2), 280-297.

Taufiq Rochim (2001). Spesifikasi, Metrologi, \& Kontrol Kualitas Geometris. Bandung: ITB. 